\title{
European research heads move to sharpen their talons
}

Munich. The heads of Europe's main national research funding organizations, who have been meeting informally for nearly two years to discuss how their organizations can work more closely with the European Commission's (EC) research programmes, have decided to set themselves up as a formal body to give themselves a stronger voice within the European Union (EU).

Meeting in Madrid last week, the group, known as the Eurohorcs (for European heads of research councils) decided to elect a president when it meets next spring. In the meantime, José Mato of Spain's CSIC is temporarily holding the reins of a newly formed steering committee.

The impetus for the formal establishment of the group was its members' disappointment that the EC research commissioner, Antonio Ruberti, excluded a Eurohorcs representative when he set up his 100 -strong advisory European Science and Technology Assembly (ESTA) last September (although many of those appointed to ESTA also happen to be Eurohorcs).

Such a representative would have had a much more powerful voice in ESTA because he or she could have spoken for all EU research organizations, says Jan Borgman, head of the Dutch NWO, who is also chairman of the assembly.

Borgman says that national research councils have a strong interest in EU research programmes, which have much larger budgets now than in the recent past.

The Eurohorcs want a greater influence on EU research policy and to be more closely involved in coordinating both national and European-wide research programmes. They also want more direct links with the $\mathrm{EC}$ in Brussels.

Such plans could conflict with the goals of the European Science Foundation (ESF), based in Strasbourg, which had also been hoping to develop a similar advisory role in Brussels (see Nature 366, 193; 1993).

Many smaller EU countries would have liked the Eurohorcs and the ESF to have joined forces, combining the resources of the ESF's secretariat and scientific staff with the politically powerful Eurohorcs in order to achieve shared aims. But some larger countries preferred a more direct role in Brussels, and did not want their influence diluted through ESF.

Both sides insist that there is no conflict of aims, and representatives from each will attend the other's meetings. Meanwhile the ESF is continuing to carry out a strategic reappraisal of its activities and a search for a new identity. Both will be top of the agenda when its general assembly meets in Strasbourg this week.

Alison Abbott

\section{NIH seeks bids for vector centres for gene therapy}

Washington. The US National Institutes of Health (NIH), concerned that clinical trials of gene therapy are being held back because of the difficulty faced by researchers in obtaining suitable vectors, have announced that they will award $\$ 3.5$ million next year to establish a small number of National Vector Laboratories.

In requesting applications to run these centres, the NIH says that the failure to accommodate researchers' needs for vector production "constitutes a barrier to progress in the field of gene therapy".

Several factors have given rise to the present situation. First, producing new vectors is expensive, as those to be used in humans must be manufactured in facilities that meet stringent requirements laid down by the Food and Drug Administration (FDA).

Second, many of the small companies that might have produced vectors on a contracts basis have recently gone out of business. Finally, biotechnology companies still in a position to do so face a shortage of capital, and are under pressure from investors to produce immediate results.

Gary Nabel, an investigator for the Howard Hughes Medical Institute at the University of Michigan in Ann Arbor, describes the NIH initiative as "less than would be ideal, but we have to start somewhere". Nabel's group is one of the few that make their own vectors and may bid to become a national centre.

Researchers at Michigan are already discussing possible collaborations with some of the other groups in the United States producing vectors about ways of making them available to investigators.

Malcolm Brenner, who is developing gene therapies at St Jude's Hospital in Memphis, Tennessee, describes vectors as "the key to gene therapy". Vectors include various types of virus whose genetic material is manipulated so that they cannot reproduce some types of lipid compounds. The vector targets specific cells to incorporate new genetic material into the genome. Nearly all aspects of their mechanism need to be improved. "Vector development is primitive," says Brenner. "We only have the model-T Ford."

According to Brenner, the NIH's decision to fund between one and three National Vector Laboratories means that collaboration between academic institutions and industry may be simplified. At present, investigators often need to negotiate with three or four companies for materials when establishing gene-therapy protocols. Each company is concerned that it may gain nothing from the collaboration while enhancing its competitors' products, and negotiations can therefore be protracted and complex.

The aim of such national laboratories will be to produce clinical-grade vectors for human gene therapy. The NIH expects that a few grants will be awarded before next August and that funding will continue for five years.

The resulting vectors will already have had preclinical testing, and will be made available to investigators with protocols approved both by the FDA and, if necessary, the NIH's Recombinant DNA Advisory Committee.

Helen Gavaghan

\section{New element spurs naming protest}

London. A controversy over the naming of new elements has been aggravated by the announcement last week that researchers at the Gesellschaft für Schwerionenforschung(GSI) in Darmstadt, Germany, have successfully created element 110 - but are refusing to propose a name for it.

Many physical chemists have been upset about the announcement by the International Union of Pure and Applied Chemistry (IUPAC) in September that it plans to name element 106 rutherfordium, after the New Zealand physicist Ernest Rutherford, rather than seaborgium. Seaborgium was proposed by the discoverers of element 106 at the Lawrence Berkeley Laboratory (LBL) in California in honour of the Nobel prizewinner Glenn T. Seaborg (see Nature 371, 639; 1994).

Although the paper describing the new element is not expected to be published until the end of December (in the journal Zeitschrift für Physik), the GSI group, led by Sigurd Hofman, were sufficiently confident of their 'discovery' to announce it last week. The laboratory had earlier created elements 107,108 and 109 , and, according to Peter Armbruster, head of nuclear chemistry at GSI, the group is more confident of its latest discovery than when it announced ' 109 ' in 1984.

But the discoverers are still unhappy with the names proposed for the earlier elements by the IUPAC Commission on Nomenclature of Inorganic Chemistry. GSI had suggested nielsbohrium (107), after physicist Niels Bohr, hassium (108) after Hassia, the latin name for the region in which GSI is located and meitnerium (109) after the physicist Lise Meitner. But the names proposed by the IUPAC 


\section{Gloomy prospects face biodiversity treaty}

Washington. As delegates prepare to meet next week in the Bahamas to negotiate details of the international Convention on Biological Diversity, signatories to the treaty, approved by the Earth Summit in Rio de Janeiro in 1992, remain as divided as ever on several important issues.

These range from how the convention should be funded to the possible implications of a bid to impose a moratorium on trade in genetically engineered plants and animals. Furthermore, with the United States still putting off ratifying the treaty, the prospects for settling those issues appear worse than at any time since the convention came into being.

President Bill Clinton signed the biodiversity treaty last year. But the Senate failed to ratify it, leaving the United States as merely a non-voting 'observer' at the Bahamas meeting. So far, 167 countries have signed the convention and 97 have ratified it, including all the other major industrial nations.

Much of the business at this first conference of parties, which runs from 28 November to 9 December, will be administrative, setting up rules and procedures. But the signatories will also face some of the divisive issues that have so far been avoided through vague wording of the treaty -- such as the transfer of technology to developing nations, and the sharing of patent royalties for products developed from native biological resources.

The agreed interim funding mechanism is the Global Environment Facility (GEF), administered by the World Bank. The United States and other industrial nations would like to make that arrangement permanent. But many developing nations, who want a greater say in which projects receive fund-

committee and due to be ratified by the IUPAC Council at its meeting in Guildford, England, next year, are bohrium, hahnium and meitnerium respectively.

"The discovers have the right to name an element, and IUPAC can accept it or not," says Armbruster. "But if they don't, they should tell you and allow you to come up with another name, not invent another name themselves."

The group are particularly unhappy because they wanted to honour Lise Meitner, who worked with Otto Hahn. He was awarded the Nobel prize for chemistry in 1944 for their joint work on the discovery of the fission of heavy nuclei. But Meitner received nothing and her contribution to the work is generally overlooked. The group did not want the names to be used for adjacent elements.

Their dissatisfaction is echoed by Albert Ghiorso, senior nuclear scientist ing, are likely to resist.

Intergovernmental meetings held over the past two years to lay the groundwork for next week's conference have made little progress in deciding what kinds of projects should even be funded. They have agreed on easy projects, such as taking biological invento-

\section{IMAGE UNAVAILABLE FOR COPYRIGHT REASONS}

Still at issue: how to fund projects aimed at preserving genetic resources.

ries. But they have argued over how and where conservation programmes should be set up - for example, whether money should be spent preserving known 'hot spots' of biodiversity, or be more evenly distributed between countries

Another potentially explosive issue is 'bio-safety' - the purported danger of introducing genetically engineered organisms into the natural environment. Even though the matter is not on the agenda, several nations including India, as well as a number of environmental groups, want to raise it.

Richard Godown, a senior vicepresident at the US Biotechnology Industry Organization, which represents the interests of biotechnology companies, says that he does not believe a moratorium on trade in genetically engineered plants and animals

emeritus at LBL, and leader of the team that discovered element 106. "The right of discoverers to name elements is sacrosanct," says Ghiorso.

In view of the current dispute, the German group has decided not to propose a name for the new element. It says that it has sent a letter to IUPAC explaining its disagreement with the way the earlier elements were named and that it will "do everything" it can to force IUPAC to reconsider its proposals before the ratification meeting in Guildford.

Ghiorso is confident that, faced with widespread opposition, the IUPAC will back down. And he, for one, will continue to call the elements by the names suggested by their discoverers: rutherfordium (104), hahnium (105), seaborgium (106), nielsbohrium (107), hassium (108) and meitnerium (109).

Maggie Verrall will be agreed. But he describes it as a "dangerous idea to have floating around" at the Bahamas meeting.

Concern about such potential restrictions has fuelled US opposition to the biodiversity convention. Conservative Republicans in particular cite the treaty's vagueness on protecting intellectual property rights, and possible - though some say unlikely -restrictions on private property owners, as reasons not to sign.

Following the recent Republican congressional victories, the committee that oversees ratification of the treaty will now be chaired by one of its most vigorous opponents, Senator Jesse Helms of North Carolina. Republican opponents such as Helms are gambling that, even if the United States does not participate as a formal voting member, it will still wield influence at next week's meeting through its position as the largest donor to the GEF. As a Republican policy paper written in September says, "if the United States has so little support from its friends that no one will assist [it] by objecting to consensus on issues adverse to our interests, then the [Clinton] Administration had no business signing this convention".

But US reluctance to ratify may also encourage developing nations to pursue their own agendas at the meeting. Even if the United States dropped out of the convention, the GEF would still amount to some $\$ 1.5$ billion, nearly half of which would be used for programmes under the biodiversity convention.

Many US conservationists and biologists say the United States will be the loser if it chooses not to ratify. "The United States lost an amazing amount by not signing the convention early," says Daniel Janzen of the University of Pennsylvania. Now, he claims, US researchers are viewed with suspicion when they go prospecting for biological resources in other countries.

Godown agrees, and warns that if the United States does not sign, developing countries may choose to work instead with biotechnology companies from countries that have agreed to accept its rules.

An indication of the tensions likely to surface at next week's meeting have already come from the Convention on International Trade in Endangered Species (CITES) that ended last week in Florida, and which saw fireworks over, among other issues, proposed new criteria for listing species as protected.

The US delegation successfully fended off an attempt to apply rigid - and scientifically unjustifiable - numerical criteria on population size and size of habitat that would have allowed trade in certain whales, apes, and other species.

Tony Reichhardt 